\title{
Wybory organu wykonawczego gminy w wielkich miastach - determinanty sprzyjające utrzymaniu władzy
}

\author{
The election of local government in the large cities - \\ determinants which are conducive to maintain the authority
}

\section{Streszczenie:}

Dokonana w 2002 r. istotna zmiana zasad i trybu wyboru organu wykonawczego samorządu w jego podstawowych jednostkach organizacyjnych otwierała kolejny etap rozwoju polskiego samorządu terytorialnego. Wówczas nastąpiło odejście od wyboru wójta (burmistrza, prezydenta miasta) przez radę gminy/miasta. Ustanowiona została zasada bezpośredniej elekcji tego organu, dokonywanej przez mieszkańców. Od 2002 r. prezydenci miast są wybierani co 4 lata w wyborach bezpośrednich. Kolejne wybory przynosiły ponowne zwycięstwo urzędującym prezydentom w wielu miastach. Określa się ich mianem „wiecznych prezydentów” (wielokadencyjni prezydenci).

Wyznaczając przestrzenny zakres empirycznego pola badawczego, wybrałam trzy największe miasta Polski: Kraków, Gdańsk i Wrocław. Przebieg kampanii związanych $\mathrm{z}$ wyborami prezydentów tych miast odsłania szczególnie interesujące aspekty pozycji i trudnej w modernizującej się Polsce realizacji zadań przypisanych po 2002 r. prezydentom.

Artykuł jest próbą pokazania specyfiki władania prezydenta polskiego miasta wybieranego co najmniej trzykrotnie. Moim celem badawczym było 
Grażyna Szczęsna - Wybory organu wykonawczego gminy...

prześledzenie wydarzeń i okoliczności, które determinowały pozycję organu wykonawczego gminy i sprzyjały reelekcji.

Słowa kluczowe: polityka lokalna; wybory prezydentów miast; wielokadencyjni prezydenci, władza lokalna.

\begin{abstract}
:
The significant change of the principles and manner of electing the executive body of the local government in its basic organizational units introduced in 2002 opened another chapter of development of the Polish local government. The principle of electing the village mayor (mayor, president of the city) by the commune/city council was cancelled. It was established that this body would be elected directly, by the commune dwellers. Since 2002, town mayors in Poland have been elected in direct elections every four years. The next elections were bringing the renewed victory of presidents-in-office in many cities. They are named „everlasting mayors” (multi-term mayors).

While defining the territorial scope of the empirical research I chose three of the biggest cities in Poland: Cracow, Gdansk and Wroclaw. The course of campaigns connected with the election of presidents of these cities displays particularly interesting aspects of the position and the difficulties in fulfillment of tasks assigned to the presidents after 2002 in Poland under modernization. The article is an attempt to show the specificity mayor of Polish city who is in term of office for at least three times. My research objective was to analyze the events and circumstances which determined the position of the commune executive body and conduced to re-election.
\end{abstract}

Keywords: local politics; mayor of town elections; multi-term mayors; local power.

\title{
Wprowadzenie
}

Miasta polskie, w których organem wykonawczym jest prezydent (107 miast), mają zróżnicowany charakter zarówno pod względem demograficznym, ekonomicznym i terytorialnym. Wśród nich znajdują 
się miasta na prawach powiatu oraz takie, które nie są powiatami grodzkimi1. Niektóre z nich to wielkie aglomeracje metropolitalne.

Zarządzanie wielkimi miastami to specyficzny przypadek sprawowania władzy w środowisku lokalnym. Szczególnie dlatego, że są one zupełnie różne od środowisk gminnych, gmin wiejskich, miast małej i średniej wielkości. Wielka liczba mieszkańców, często ogromna, zurbanizowana przestrzeń rodzą problemy życia zbiorowego, które w małych środowiskach właściwie nie występują. A jeśli już występują to z pewnością nie w takiej skali.

Artykuł jest próbą pokazania specyfiki pozycji prezydentów polskich miast wybieranych na kolejne kadencje w trzech największych miastach Polski m.in.: Gdańsku, Krakowie i Wrocławiu, począwszy od pierwszych bezpośrednich wyborów (2002 r.). Podstawowym celem przeprowadzonych badań było poddanie weryfikacji przyjętego założenia, że jednym z zasadniczych czynników motywujących do zabiegania o władzę przez prezydentów miast jest poparcie mieszkań-

\footnotetext{
1 W efekcie wprowadzenia ustawy z 5 czerwca 1998 r. o samorządzie powiatowym (tekst jedn. Dz. U. z 2016 r., poz. 814 ze zm.) w Polsce utworzono 373 powiaty, spośród których 65 stanowiły miasta na prawach powiatu, określane jako powiaty grodzkie, w przeciwieństwie do pozostałych nazywanych ziemskimi. Choć w ustawie nie pojawiają się pojęcia „powiat ziemski” i „powiat grodzki”, to na odróżnienie jednych od drugich powszechne stało się używanie tych terminów. Zob. T. Kuczur, Istota i funkcjonowanie nowoczesnego samorządu terytorialnego $w$ Polsce - wprowadzenie do problematyki, [w:] R. Bruski, J. Joachimowski, T. Kuczur (red.), Współczesna administracja publiczna w Polsce, Wybrane zagadnienia prawe, polityczne i ekonomiczne. Wyd. Mado, Toruń 2010, s. 19. Dla uściślenia informacji o powiatach grodzkich należy wspomnieć o dwóch miastach - Warszawie i Wałbrzychu - których status ulegał przeobrażeniom w tym względzie. Warszawa była siedzibą istniejącego w latach 1999-2002 powiatu warszawskiego, a jednocześnie stolica funkcjonowała także na podstawie wielokrotnie nowelizowanej tzw. ustawy warszawskiej (ustawa z dnia 25 marca 1994 r. o ustroju miasta stołecznego Warszawy, Dz.U. z 1994 r. Nr 48, poz. 195 ze zm.). 15 marca 2002 r. przyjęto jednak nową ustawę o ustroju miasta stołecznego Warszawy (tekst jedn. Dz.U. z 2015 r., poz. 1438), na mocy której od 27 października $2002 \mathrm{r}$. Warszawa uzyskała status miasta na prawach powiatu i tym samym stała się 66 powiatem grodzkim. Jednak od 1 stycznia 2003 r. do 31 grudnia 2012 r. w Polsce funkcjonowało ponownie 65 powiatów grodzkich, ponieważ w okresie tym miasto Wałbrzych stanowiło gminę miejską, wchodzącą w skład ziemskiego powiatu wałbrzyskiego. Od 1 stycznia 2013 r., po kilkuletnich staraniach władz miasta, Wałbrzych ponownie stał się powiatem grodzkim.
} 
Grażyna Szczęsna - Wybory organu wykonawczego gminy...

ców, które jest konsekwencją akceptowania przez nich sposobu sprawowania władzy oraz efektów jej działań. W toku prowadzonych badań poszukiwałam również odpowiedzi na pytania:

1. Czy, a jeśli tak, to w jakim stopniu wpływ na wybory prezydenta miasta posiada charakter komitetu wyborczego kandydata? Wyborcy preferują komitety partyjne, czy lokalne?

2. Jakie kwalifikacje i umiejętności prezydentów miast są najważniejsze w sprawnym zarządzaniu miastem?

3. Jakie czynniki decydowały o zwycięstwie w wyborach prezydentów w trzech wybranych wielkich miastach polskich?

Osiągnięcie założonego celu badawczego wymagało posłużenia się metodą ilościowo-jakościową, przydatną przy opracowaniu materiałów źródłowych dotyczących wyników wyborów. Metoda komparatystyczna została wykorzystana w celu porównania uzyskanych wyników przez głównych uczestników opisywanych batalii wyborczych. Opierałam się w tym zakresie przede wszystkim na danych statystycznych przygotowanych przez Państwową Komisję Wyborczą. Jednocześnie analizy statystyczne zostały poszerzone i wzmocnione poprzez odwołanie się do badań jakościowych, które zostały oparte na analizie materiałów prasowych, wypowiedzi polityków i innych źródeł publikowanych w czasie wyborów. Ograniczone ramy opracowania nie pozwalały odwoływać się do wielu innych źródeł i pozycji literatury przedmiotu. Świadomie też ograniczam swoje rozważania do wybranych przypadków, dążąc do ukazania charakteru i przebiegu rywalizacji o fotel prezydenta.

Sytuacja społeczna, polityczna i gospodarcza wielkich miast jest interesującym obszarem dla badaczy procesów związanych bezpośrednio z organizowaniem życia zbiorowego ich mieszkańców i kierowaniem nim. $W$ tej przestrzeni rozwiązywane być muszą wszelkie problemy zaspokajania indywidualnych i zbiorowych potrzeb, zabezpieczania interesów ogromnej, ale ciągle lokalnej, społeczności. Tu również najbardziej wyraziście widoczne są osiągnięcia, lecz i niedostatki cywilizacyjno-kulturowe. Rozwiązywanie wskazanych proble- 
mów jest główną treścią codziennej działalności organów lokalnej władzy, której prezydent miasta jest najbardziej prominentnym przedstawicielem. Miast, w których władzę sprawują „wieczni prezydenci" jest wiele. W latach 2002-2010, w 30 miastach na prawach powiatu na prezydentów wybierano ponownie te same osoby. W 2014 r. trzech z nich zrezygnowało z rywalizacji o fotel prezydenta, dziesięciu przegrało wybory, natomiast siedemnastu z nich po raz kolejny uzyskało mandat. Władzę co najmniej ${ }^{2}$ na czwartą kadencję zdobyli włodarze m.in. w Gdyni, Gliwicach, Jaworznie, Rzeszowie, Sopocie, Tychach.

Zjawiska i procesy zachodzące w miastach Polski, wybranych jako obiekty analizy rywalizacji wyborczej o urząd prezydenta, są w dostatecznym stopniu reprezentatywne, by ukazywać cechy wspólne i różnice wynikające ze specyfiki poszczególnych ośrodków. Na tej podstawie można podjąć próbę wskazania uwarunkowań i przyczyn ponownego wyboru „głównych architektów polityki lokalnej”.

\section{Kraków}

Po wyborach z listopada 2014 r. można powiedzieć, że Kraków jest miastem, w którym o stanowisko prezydenta rywalizuje wielu znakomitych kandydatów, a zawsze wygrywa - jak dotąd - Jacek Majchrowski. Faktycznie, od wprowadzenia bezpośrednich wyborów, czyli od 2002 r., J. Majchrowski czterokrotnie okazywał się ich zwycięzcą. Co prawda za każdym razem do ostatecznego wyłonienia zwycięzcy niezbędna była druga tura wyborów.

W aspekcie ideowym mieszkańcy Krakowa przychylni są raczej postawom i hasłom konserwatywnym, co niewątpliwie jest dziedzictwem historii tego miasta, jego tradycji, silnych wpływów oraz pozycji

\footnotetext{
2 Wśród 17 wielokadecyjnych prezydentów kilku z nich po raz pierwszy zasiadało na fotelach prezydenckich jeszcze przed 2002 r. np. od 1993 r. - Zygmunt Frankiewicz w Gliwicach; od 1998 r. - Wojciech Szczurek w Gdyni, Jacek Karnowski w Sopocie; od 2000 r. - Andrzej Dziuba w Tychach.
} 
Grażyna Szczęsna - Wybory organu wykonawczego gminy...

kościoła katolickiego. Należy zwrócić uwagę, że w innych wyborach w Krakowie zdecydowanie i bezwzględnie najwyższym poparciem cieszą się kandydaci i ugrupowania szeroko rozumianej prawicy, reprezentowanej przez $\mathrm{PO}$ oraz $\mathrm{PiS}^{3}$.

W 2002 r. wywodzący się z SLD J. Majchrowski został prezydentem Krakowa, pokonując takich rywali jak Jan Maria Rokita (PO), Zbigniew Ziobro (PiS) i byłego prezydenta oraz zwycięzcę pierwszej tury wyborów Józefa Lassotę (kandydata swojego własnego Obywatelskiego Komitetu Wyborczego Wyborców „Twoje Miasta”) ${ }^{4}$. W I turze wyborów J. Lassota uzyskał 21,18\% poparcia a J. Majchrowski o ok. 2\% niższe.

Ostateczny wynik wyborów był niespodzianką i wielkim zaskoczeniem w skali całego kraju, tym bardziej, że J. Majchrowski nie był nawet kandydatem zgłoszonym przez SLD, lecz wystartował z ramienia Ponadpartyjnego Komitetu Wyborczego Wyborców „Przyjazny Kraków”. ${ }^{\prime \prime}$ W drugiej turze głosowania wygrał z J. Lassotą o 1421 głosów. Zwycięstwo J. Majchrowskiego było w głównej mierze rezultatem pozytywnego społecznego postrzegania zarówno jego samego jako kan-

${ }^{3} \mathrm{Na}$ podstawie danych zaczerpniętych z oficjalnej strony internetowej Państwowej Komisji Wyborczej - www.pkw.gov.pl, w wyborach parlamentarnych w $2007 \mathrm{r}$. łącznie na listy tych dwóch partii oddano w Krakowie aż 82,12\% głosów (PO 52,57\%, PiS - 31,55\%). Natomiast w 2005 r. powyższe partie uzyskały 73,19\%, w tym PO - 33,98\%, PiS - 39,21\%. Podobnie wyglądała sytuacja jeśli chodzi o wybory prezydenta RP. W 2010 r. kandydaci PO i PiS uzyskali łącznie w pierwszej turze głosowania 81,01\% głosów (Bronisław Komorowski - 48,66\%, Jarosław Kaczyński $32,35 \%)$.

4 Pierwsza tura wyborów zakończyła następującymi wynikami: Józef Lassota 23,27\%, Jacek Majchrowski - 21,18\%, Jan Maria Rokita - 18,06\%, Zbigniew Ziobro 12,93\%, Kazimierz Kapera - 9,19\% (wszystkich kandydatów było 13, ale wyniki pozostałych kandydatów nie przekraczały 5\%). W drugiej turze Jacek Majchrowski (50,47\%), pokonał Józefa Lassotę - (49,53\%) przewagą zaledwie 1421 głosów - dane PKW (www.pkw.gov.pl.).

5 W wyborach do Rady Miasta Krakowa komitet ten uzyskał zaledwie 3,6\% głosów, czyli nawet nie przekroczył progu wyborczego. Wybory te wygrało PiS $(17,22 \%$ i 9 mandatów w Radzie) przed koalicja SLD-UP (16,87\% - 10 mandatów), LPR (16,12\% - 9 mandatów), PO (13,73\% - 7 mandatów) i KWW Józefa Lassoty (12,41\% - 7 mandatów). Ostatni - 43. mandat przypadł KWW Krakowska Platforma Samorządowa - dane PKW (www.pkw.gov.pl). 
dydata, jak również jego programu wyborczego. Poza tym korzystny wynik osiągnął również z powodu wewnętrznego podziału krakowskiej prawicy, jak również wzajemnych antypatii personalnych jej kandydatów. Konsekwencją nieporozumień na prawicy był brak przy drugiej turze wyborów jednoznacznego i oficjalnego poparcia dla J. Lassoty ze strony wszystkich przegranych w pierwszej turze kandydatów i ich komitetów wyborczych. J. Majchrowski był faktycznie jedynym faworytem na to stanowisko.

W kolejnych wyborach prezydenckich w 2006 r. w Krakowie rywalizowało ze sobą siedmiu kandydatów. Najmocniejszym kontrkandydatem J. Majchrowskiego był prof. Ryszard Terlecki, historyk (UJ, PAN), wykładowca i dziennikarz oraz działacz NSZZ „Solidarność”. R. Terlecki występował z ramienia PiS, przegrał $\mathrm{w}$ drugiej turze stosunkiem głosów 40,43\% do 59,57\% na korzyść Majchrowskiego przy frekwencji 38,84 \%6. R. Terlecki do momentu rozpoczęcia kampanii wyborczej był osobą kompletnie nieznaną. Wyborcy dowiadywali się o nim z billboardów, uzyskując informacje, że jest profesorem i reperzentuje PiS.

J. Majchrowski przez swoją drugą kadencję na stanowisku prezydenta Krakowa efektywnie i umiejętnie zarządzał miastem. W skutecznym sprawowaniu władzy sprzyjały prezydentowi zarówno polityczna słabość i podziały wewnątrz krakowskiej PO, a później również wewnątrz PiS. Prezydent w drugiej kadencji wykazał się: modernizacją Małego Rynku i Placu Wszystkich Świętych, otwarciem Muzeum Historii Miasta Krakowa pod płytą Rynku Głównego, remontem ulicy Długiej, otwarciem parkingu podziemnego w pobliżu Wawelu (plac Na Groblach), przebudową stadionu Cracovii, budową i otwarciem Krakowskiego Szybkiego Tramwaju oraz ukończeniem i oddaniem dwóch najważniejszych inwestycji - rond Grzegórzeckiego i Mogil-

${ }^{6}$ Na podstawie danych PKW (www.pkw.gov.pl). 
Grażyna Szczęsna - Wybory organu wykonawczego gminy...

skiego. Została także otwarta nowa część terminalu międzynarodowego lotniska w Balicach?

W 2010 r. J. Majchrowski po raz trzeci odniósł zwycięstwo w wyborach na prezydenta Krakowa. Wówczas startował jako niezależny kandydat, choć nadal kojarzony ze środowiskiem lewicowym, wystawiony został przez KWW Jacka Majchrowskiego. Trzeba zaznaczyć, że od samego początku kampanii wyborczej wiadomo było, że wybory te rozstrzygną się między dwójką kandydatów - urzędującym prezydentem Krakowa J. Majchrowskim i urzędującym wojewodą małopolskim Stanisławem Kracikiem. Jedyną osobą, która w tych wyborach mogła odegrać istotną rolę i zaburzyć rywalizację pomiędzy kandydatami był kandydat PiS Andrzej Duda.

W pierwszej turze bezdyskusyjnie zwyciężył J. Majchrowski, zdobywając 40,78\% głosów. Natomiast jego rywal S. Kracik uzyskał 33,69\% poparcia. Trzeba powiedzieć, że zadawalający wynik $(22,38 \%)$ uzyskał również A. Duda8.

Największe szanse w drugiej turze wyborów wciąż miał J. Majchrowski, chociaż przy uzyskanym poparciu przez S. Kracika i silnym na jego rzecz poparciu PO wszystko mogło się jeszcze zmienić. Bardzo ważne w tym momencie było poparcie A. Dudy, na którego w pierwszej turze zagłosowała $1 / 4$ wyborców, którzy wzięli udział w pierwszej turze. Dlatego też zarówno J. Majchrowski jak i S. Kracik zaczęli zabiegać o poparcie ze strony kandydata PiS. Ostatecznie A. Duda poparł kandydaturę urzędującego prezydenta, jednocześnie negatywnie rekomendując jego kontrkandydata - S. Kracika. J. Majchrowski popierany przez środowiska lewicowe oraz PSL, Ruch Wyborców Janusza Korwin-Mikkego pokonał kandydata PO S. Kracika stosunkiem głosów 59,55\% do 40,45\% przy frekwencji 34,98\% ${ }^{9}$. I tak został

${ }^{7}$ R. Żurek, Recepta na „długowieczność” wójta. Analiza czynników prowadzacych do reelekcji w wyborach 2010 r. na wybranych przykładach, „Prace Naukowe Akademii im. Jana Długosza w Częstochowie. Res Politicae” 2012; Wydanie specjalne: Samorząd miejski i jego elity, s. 163.

${ }^{8}$ Na podstawie danych PKW (www.pkw.gov.pl).

${ }_{9} \mathrm{Na}$ podstawie danych PKW (www.pkw.gov.pl). 
wybrany na trzecią kadencję. Zdecydowanie na jego korzyść zadziałały pewne szczególne okoliczności. Przede wszystkim należy tu wymienić profesjonalne przygotowanie uroczystości pogrzebowych Prezydenta Lecha Kaczyńskiego i jego małżonki - ofiar katastrofy smoleńskiej.

Kolejną nadzwyczajną okolicznością, która wpłynęła na wzrost poparcia dla J. Majchrowskiego, a tym samym wzbudziła niechęć do wojewody S. Kracika, była postawa tych polityków podczas powodzi z maja 2010 r. Władze Krakowa wywiązały się bardzo solidnie z ochrony mieszkańców przed skutkami tej klęski żywiołowej. Natomiast służby wojewódzkie, za które odpowiedzialny był wojewoda Kracik, nie do końca poradziły sobie ze skutkami powodzi, gdyż wiele miejscowości w Małopolsce jeszcze przez długi czas pozostawało odciętych od świata.

Sprzymierzeńcem prezydenta J. Majchrowskiego okazała się również aura, kiedy dzień przed drugą turą wyborów Kraków sparaliżowały obfite opady śniegu. Wówczas służby miejskie bez zarzutu poradziły sobie z zaistniałą sytuacją, co dowiodło sprawności działania władz miejskich.

W ostatnich wyborach samorządowych w Krakowie, w 2014 r., J. Majchrowski po raz kolejny - na czwartą kadencję - został wybrany na prezydenta Krakowa. W wyścigu „o klucze” do miasta Krakowa rywalizowało osiem osób. Trzeba zaznaczyć, że J. Majchrowski u progu rozpoczęcia kampanii wyborczej był bezsprzecznie zdecydowanym faworytem do ostatecznego zwycięstwa. Jeżeli nie w pierwszej, to bez wątpienia w drugiej turze. Jedyną osobą, która w tych wyborach miała szansę na pojedynek z urzędującym prezydentem był Marek Lasota dyrektor krakowskiego oddziału IPN, który w kończącej się kadencji zasiadał w klubie PO sejmiku województwa małopolskiego.

Komitet Wyborczy Wyborców J. Majchrowskiego prowadził kampanię pod hasłem "Łączy nas Kraków”. W zasadzie już samo hasło bardzo dokładnie opisywało filozofię przyjętą przez sztabowców prezydenta $\mathrm{w}$ przygotowaniu i opracowaniu programu wyborczego. 
Grażyna Szczęsna - Wybory organu wykonawczego gminy...

Główny nacisk został w nim położony na eksponowanie sukcesów Krakowa pod rządami aktualnego prezydenta, a także konieczność kontynuacji - wspólnie z mieszkańcami - pracy dla dobra Krakowa. Tę jedność z mieszkańcami i niejako odwołanie się do nich bezpośrednio, ponad podziałami politycznymi, J. Majchrowski bardzo wyraźnie akcentował już w akapicie otwierającym program wyborczy: „Prosząc o poparcie po raz czwarty, deklaruję, że będę pilnował tego, co wspólnie udało nam się osiągnąć i zadbam o to, byśmy wszyscy odczuli korzyść z ważnych inwestycji, nowych dróg i obiektów użyteczności publicznej - przedsięwzięć już zrealizowanych i tych, które podejmiemy.

Nasze miasto jest gotowe, by stawić czoła wyzwaniom nowej epoki. I teraz możemy mocniej skupić się na zwykłej codzienności: zadbać o dalszy rozwój ekologicznej komunikacji, o czyste powietrze i poziom edukacji, o jakość i estetykę naszego najbliższego otoczenia, tworzyć piękne tereny zielone i powszechnie dostępne miejsca rekreacji, budować przedszkola, rozwijać programy aktywizujące bezrobotnych, wspierające rodziny i seniorów, inicjować działania sprzyjające przedsiębiorczości. A wszystko to przy Państwa udziale, dzięki uspołecznieniu procesów decyzyjnych"10.

Prezydent J. Majchrowski w kadencji 2014-2018 zamierzał skupić się przede wszystkim na poprawie komfortu życia w Krakowie. W swoich założeniach programowych sporo miejsca poświęcił ekologii. Według niego należy bezwzględnie kontynuować działania zmierzające do poprawy jakości powietrza w Krakowie poprzez: wymianę pieców węglowych, tworzenie nowych parków, zakup ekologicznego taboru komunikacji miejskiej oraz uprzywilejowanie pojazdów elektrycznych. Zapowiadał również rozbudowę infrastruktury sportowej. W pierwszej kolejności prezydent J. Majchrowski wymieniał budowę kompleksu sportowo-rekreacyjnego z basenem przy ul. Eisenberga,

${ }^{10}$ Kraków nas łączy - program wyborczy Jacka Majchrowskiego. Tekst dostępny na stronie internetowej http://www.majchrowski.pl w zakładce „program wyborczy” (data dostępu: 3.03.2015 r.). 
a także modernizację obiektów sportowych Juvenii, Hutnika, oraz Wawelu, jak również budowę hali do uprawiania sportu przez osoby niepełnosprawne. Aby Kraków utrzymał swoją pozycję stolicy kultury, J. Majchrowski zapowiadał konieczność rozbudowy miasta w tej dziedzinie na najwyższym światowym poziomie, $m$. in. poprzez: otwarcie nowoczesnej, interaktywnej ekspozycji w zabytkowym wnętrzu Muzeum Teatralnego przy ul. Szpitalnej, przejęcie przez miasto opieki nad „Rydlówką” i włączenie tego muzeum w struktury Muzeum Historycznego Miasta Krakowa. Prezydent w najbliższej kadencji chciał również zadbać o uczniów krakowskich szkół, aby mogli korzystać z jak najszerszej palety zajęć dodatkowych. Za bardzo ważny uważał projekt codziennej lekcji języka angielskiego, a także zamiar wprowadzenia dla uczniów techników i szkół zawodowych zajęć z języka obcego branżowego. Natomiast jeśli chodzi o inwestycje, prezydent w swoim programie wyborczym uznał za najważniejsze te, które poprawią komunikację w Krakowie: domknięcie III obwodnicy miasta, budowa Trasy Łagiewnickiej, linii tramwajowej do Górki Narodowej, budowę $150 \mathrm{~km}$ ścieżek rowerowych, a także przebudowę i rozbudowę kilku ulic ${ }^{11}$.

Pierwsza runda wyborczego starcia o fotel prezydenta miasta, w dniu 16 listopada 2014 r., nie przyniosła rozstrzygnięcia. Co prawda urzędujący prezydent wygrał pierwszą turę wyborów uzyskując 39,18\% poparcia, ale nie uzyskał wymaganej do zwycięstwa większości. Natomiast popierany przez PiS kandydat prawicy M. Lasota uzyskał 26,95 \% poparcia ${ }^{12}$. Kiedy już było wiadomo, że w drugiej turze zmierzą się ze sobą J. Majchrowski i M. Lasota, urzędującego prezydenta zdecydowało się poprzeć PO. Lokalni politycy PO wiedzieli, że wygrana J. Majchrowskiego gwarantuje im utrzymanie znacznych wpływów w krakowskim magistracie ${ }^{13}$. Trzeba zaznaczyć, że dla pre-

11 Tamże.

$12 \mathrm{Na}$ podstawie danych PKW (www.pkw.gov.pl).

13 http://wyborcza.pl/1,91446,17055770,Krakow_Czwarta_kadencja_prezydenta _Jacka_Majchrowskiego.html (data dostępu: 1.12.2016 r.). 
Grażyna Szczęsna - Wybory organu wykonawczego gminy...

zydenta kluczowe znaczenie $\mathrm{w}$ drugiej turze miały głosy trzeciego z kandydatów, M. Pateny. I tak 30 listopada 2014 r. w drugiej turze wyborów J. Majchrowski pokonał kandydata PiS-u M. Lasotę stosunkiem głosów 58,77\% do 41,23\% i został wybrany na czwartą kadencję $^{14}$.

Wygrana J. Majchrowskiego nie była dla nikogo zaskoczeniem. Zwycięstwo odniósł dzięki poparciu wyborców PO. Jest już regułą, że jego wygrana umożliwia brak porozumienia między ugrupowaniami prawicy oraz centroprawicy przy wyłonieniu jednego silnego kandydata. J. Majchrowski zawsze zyskuje na antagonizmie między PO i PiS. Prezydent trafnie odczytuje też charakterystyczne dla Krakowa oczekiwania mieszkańców, którzy chcą spokojnych, gospodarskich rządów. Kolejne zwycięstwo J. Majchrowskiego to efekt przyzwyczajenia, które jest nieodłącznym elementem mentalności krakowian. Można powiedzieć, że w Polsce zachodzi proces stabilizacji władzy samorządowej i J. Majchrowski jest tego beneficjentem. Jednorazowe epizody nie wpływają na obniżenie notowań. Zamieszanie z igrzyskami zimowymi, z budżetem obywatelskim i otoczka wokół tego nie wpłynęły na wyniki wyborów ${ }^{15}$.

Można powiedzieć, że przypadek J. Majchrowskiego jest dość nietypowy. Właściwie w wyborach z 2002 r. można było go postrzegać jako kandydata niby bezpartyjnego, to kolejne elekcje pokazywały dystans kandydata w stosunku do SLD i umiejętność wykorzystania elektoratu tej partii. Krótko mówiąc, J. Majchrowski jako lider lokalny, umiejętnie wykorzystał wizerunek bezpartyjnego prezydenta lewicy otwartego na podmioty, które w danym czasie pozwalały na utrzymanie pozycji „wielokadencyjnego prezydenta”. Widać, że zbudował stabilną i liczną grupę wyborców, którzy gwarantują mu wygraną.

${ }^{14}$ Na podstawie danych PKW (www.pkw.gov.pl).

15 B. Piłat, To będzie kadencja administrowania. „Gazeta Wyborcza Kraków” z dnia 1.12.2014 r. 


\section{Gdańsk}

Podobnie w Gdańsku, odkąd wprowadzono bezpośrednie wybory prezydentów miast, zwycięzca jest tylko jeden: Paweł Adamowicz. Polityk PO, wygrywał dotąd każde starcie o fotel prezydenta. Najpierw w 2002 r. z Markiem Formelą, a później trzykrotnie w 2006 r., 2010 r. i 2014 r. z Andrzejem Jaworskim.

P. Adamowicz urząd prezydenta sprawuje od 1998 r.. Chociaż kadencja 1998-2002 nie jest tu analizowana ze względu na pośredni wybór, to jednak pełnienie funkcji prezydenta miasta na pewno rzutowało na jego dalsze losy. Warto również wspomnieć o karierze samorządowej P. Adamowicza. W 1990 r. został radnym Gdańska z ramienia Komitetu Obywatelskiego. W następnej kadencji (1994-1998) został przewodniczącym Rady Miasta Gdańska. Działał w tym okresie najpierw w Partii Konserwatywnej, a później w Stronnictwie Konserwatywno-Ludowym. Jednak w jego karierze przełomowy był rok 1998, wtedy został po raz trzeci radnym, z listy AWS (SKL) i w tym samym roku objął urząd prezydenta miasta. Jak widać, aktywność polityczna, urzędowa i społeczna gwarantuje znaczny stopień rozpoznawalności. Nie było więc zaskoczeniem to, że w 2002 r. w pierwszych bezpośrednich wyborach o urząd prezydenta miasta P. Adamowicz został wybrany na drugą kadencję prezydencką w Gdańsku.

Wówczas odbyły się dwie tury głosowania. W rywalizacji w pierwszej turze wyborów prezydenckich zwyciężył P. Adamowicz uzyskując $37,46 \%$ poparcia. W drugiej turze walka toczyła się pomiędzy P. Adamowiczem i M. Formelą. Zwycięzcą wyborów prezydenckich w $2002 \mathrm{r}$. został P. Adamowicz, uzyskując poparcie 72,28\% (71639 głosów) zdecydowanie pokonując rywala, kandydata SLD-UP16.

${ }^{16}$ Na podstawie danych PKW (www.pkw.gov.pl). W drugiej turze wyborów P. Adamowicza poparli B. Borusewicz, PiS i G. Strzelczyk. J. Kurski stwierdził: „Gdyby różnica między obu kandydatami była niewielka, poparłbym Adamowicza. Jednak jego przewaga jest przytłaczająca, a nie chcę, żeby ją jeszcze powiększyli moi wyborcy", G. Borkowska, Ta wyborcza niedziela. Listy do Pawła Adamowicza. „Gazeta Wyborcza Trójmiasto" z dnia 8.11.2002 r. 
Grażyna Szczęsna - Wybory organu wykonawczego gminy...

Silna pozycja PO oraz własny autorytet to główne przesłanki, które przyczyniły się do zdobycia w 2002 r. przez P. Adamowicza fotela prezydenta Gdańska. Swój sukces skomentował: „Traktowałem wyborców poważnie, nie obiecywałem gruszek na wierzbie. Byłem po stronie gdańszczan i okazało się, że oni są po mojej stronie"17.

Podsumowując wyniki pierwszych bezpośrednich wyborów organu wykonawczego miasta, można powiedzieć, że zapewniły one dosyć łatwe zwycięstwo P. Adamowiczowi. Kadencja 2002-2006 ogólnie była pozytywnie oceniana. Już w połowie kadencji zauważono poprawę stanu dróg, udało się sprzedać Gdańskie Przedsiębiorstwo Energetyki Cieplnej oraz rozpocząć budowę hali widowiskowo-sportowej. Pozytywnie oceniano podejmowane działania w celu poprawy bezpieczeństwa mieszkańców: powstanie komisariatu policji na Oruni, przekazanie 27 mieszkań na wynajem dla policjantów, miasto finansowało zakupy sprzętu, dopłacało do dodatkowych patroli, rozpoczęło budowę systemu monitoringu wizyjnego $\mathrm{w}$ dzielnicach miasta ${ }^{18}$. Poza tym zorganizowanie 25 rocznicy powstania NSZZ „Solidarność”, owocne starania o środki z UE, jak również stworzenie projektu budowy 1000 mieszkań komunalnych pozytywnie wpłynęło na obraz prezydentury P. Adamowicza. Korzystnie postrzegano stworzenie wizerunku przyjaznego i bezkonfliktowego prezydenta, chociaż niektórzy uważali, że jest to efekt skutecznie stosowanych zasad marketingu politycznego ${ }^{19}$. Podejmowane działania przez urzędującego prezydenta $\mathrm{z}$ całą pewnością wpłynęły na zwiększenie jego poparcia, co potwierdziły kolejne wybory $\mathrm{w} 2006$ r., które rozstrzygnęły się w pierwszej turze. P. Adamowicz uzyskał 60,87\% poparcia i po raz drugi (trzeci) został prezydentem Gdańska. Jego najpoważniejszym rywalem był kandydat

17 G. Borkowska, Przyjaciół poznaje się w kampanii, „Gazeta Wyborcza Trójmiasto” $\mathrm{z}$ dnia 12.11.2002 r.

18 P. Piotrkowski, K. Katka, Oceniamy bezpieczeństwo, „Gazeta Wyborcza Trójmiasto" z dnia 30.11.2004 r.

${ }^{19}$ K. Katka, K. Włodkowska, PiS chce buszować w kolebce PO. „Gazeta Wyborcza Trójmiasto" z dnia 16.01.2006 r. 
PiS - A. Jaworski (29,67\%), który uzyskał o prawie 30\% mniejsze poparcie ${ }^{20}$.

Krótko mówiąc, na sukces P. Adamowicza wpłynęły zarówno notowania partii, której był kandydatem oraz ocena prezydentury kończącej się kadencji. Jeśli chodzi o czynnik partyjny, to PO posiadało rosnące poparcie, co wyraźnie było potwierdzone w liczbie bezwzględnie oddanych na nie głosów: w 2002 r.- 32550, a w 2006 r.- 84933. Natomiast jeśli chodzi o drugi czynnik, to trzeba powiedzieć, że prezydentura P. Adamowicza była dobrze oceniana przez większość mieszkańców miasta, gdyż potrafił realizować ich potrzeby. Realne dokonania prezydenta oraz sposób ich przedstawienia wywarły znaczący wpływ na autorytet P. Adamowicza, który w 2002 r. w drugiej turze zdobył 71639 głosów, to w 2006 r. już w pierwszej turze otrzymał 96485 głosów.

Jednym z dokonań prezydenta P. Adamowicza w czasie kadencji 2006-2010 była budowa nowoczesnego stadionu na rozgrywki Euro 2012. Sukcesem była również sprzedaż prawa do nazwy stadionu Polskiej Grupie Energetycznej na 5 lat (PGE Arena) za $35 \mathrm{mln} \mathrm{zł}^{21}$. Ponadto prace związane z Trasą Sucharskiego i budową tunelu pod Martwą Wisłą, to również dokonania tego okresu.

Zgodnie z przewidywaniami wybory prezydenckie w $2010 \mathrm{r}$. w Gdańsku wygrał w I turze, już po raz trzeci, P. Adamowicz uzyskując wynik 53,78\% głosów, natomiast A. Jaworski uzyskał 21,84\% głosów. Porównując to z wynikami wyborami w 2006 r., zauważyć można, że zarówno P. Adamowicz jak i A. Jaworski uzyskali niższe poparcie niż cztery lata wcześniej. Trzeba również powiedzieć, że spadła też frekwencja wyborcza z 44,40\% głosujących w 2006 r. do 39,76\% w 2010 r.22.

${ }^{20}$ Na podstawie danych PKW (www.pkw.gov.pl).

${ }^{21}$ M. Jamroż, Narodziła się PGE Arena Gdańsk. "Gazeta Wyborcza Gdańsk” z dnia 26.05.2010 r.

22 Na podstawie danych PKW (www.pkw.gov.pl). 
Grażyna Szczęsna - Wybory organu wykonawczego gminy...

W 2014 r. w wyborach prezydenta Gdańska odbyły się dwie tury głosowania. P. Adamowicz zwyciężył w pierwszej turze uzyskując $46,05 \%$ poparcia. Natomiast jego główny rywal, A. Jaworski otrzymał 26,15\% głosów ${ }^{23}$. Uzyskany wynik przez P. Adamowicza nie dawał pewności co do rozstrzygnięcia $w$ drugiej turze. Prezydent zdawał sobie sprawę, że nie może lekceważyć rywala - kandydata PiS. Tym bardziej, że poparcia A. Jaworskiemu udzielił J. Szczukowski z SLD, na którego w pierwszej turze oddano 4,63\% głosów oraz bezpartyjny kandydat W. Bartelik z poparciem w pierwszej turze 6,58\% głosów ${ }^{24}$. Dodatkowo śledztwo prokuratorskie prowadzone od 2013 r. w sprawie oświadczenia majątkowego Adamowicza kładło cień na jego sytuację polityczną ${ }^{25}$. Ostatecznie, w dniu 30 listopada 2014 r. w drugiej turze głosowania zwyciężył P. Adamowicz zdobywając 61,25\% głosów ${ }^{26}$.

Wybory z 2014 r. zakończyły się po raz kolejny silną pozycją PO w samorządzie gdańskim. Analizując sukces P. Adamowicza należy zwrócić uwagę na kilka jego przyczyn. Jedną z nich jest szczególna pozycja PO w Gdańsku. Partia ta posiada tam wyjątkowo wysokie poparcie, podobnie z resztą jak w pozostałych miastach aglomeracji trójmiejskiej. W wyborach do Sejmu PO w 2005 r. otrzymało 46,14\%, a w wyborach prezydenckich w 2010 r. Bronisław Komorowski zdobył $57,09 \%$ głosów 27 . Dlatego też P. Adamowicz był po prostu kojarzony i utożsamiany z PO, jako członek i kandydat tej partii.

Drugim czynnikiem mającym wpływ na sukces Adamowicza były konkretne, pozytywne efekty w modernizacji Gdańska. Remonty i inwestycje $\mathrm{w}$ infrastrukturę komunalną są zawsze pozytywnie odbierane przez mieszkańców.

${ }^{23} \mathrm{Na}$ podstawie danych PKW (www.pkw.gov.pl).

${ }^{24} \mathrm{http}$ ://gdansk.naszemiasto.pl/artykul/wybory-samorzadowe-2014-w-gdansku -zbigniew-wysocki-z-knp,2528834,art,t,id,tm.html (data dostępu: 1.12.2016 r.).

$25 \mathrm{http}$ // www.polskieradio.pl/5/3/Artykul/1305438,II-tura-wyborow-wGdansk u-PKW-wygral-Pawel-Adamowicz (data dostępu: 1.12.2016 r.).

${ }^{26} \mathrm{Na}$ podstawie danych PKW (www.pkw.gov.pl).

$27 \mathrm{Na}$ podstawie danych PKW (www.pkw.gov.pl). 
Trzecią a zarazem bardzo istotną przyczynę stanowi to, iż P. Adamowicz przez większą część swoich rządów w mieście miał zaplecze w Radzie Miasta, posiadającej bezwzględną większość, przez co podejmowane działania i decyzje miały większą efektywność. Przypadek P. Adamowicza potwierdza tezę, że sukces „partyjnego” kandydata na urząd prezydenta miasta jest uzależniony od podstawowych czynników, a mianowicie: notowań partii, wsparcie ze strony Rady Miasta, którą reprezentuje, jak również od ocen mieszkańców/wyborców prezydentury kończącej się kadencji.

\section{Wrocław}

Kolejnym miastem, w którym władzę sprawuje „wieczny prezydent" jest Wrocław. Cechą charakterystyczną wrocławskich wyborów lokalnych jest wzrastająca dominacja partii politycznych. Szczególnie silne pozycje zajmują ugrupowania prawicowe.

W 2002 r. w wyborczych szrankach o fotel prezydenta startowało 10 kandydatów. Od początku kampanii wyborczej respondenci sondażowi jako zwycięzcę elekcji wskazywali Rafała Dutkiewicza, przed kandydatką lewicy - Lidią Geringer d'Oedenberg28. Jednak rywalizacja nie zakończyła się w I turze. R. Dutkiewicz zdobył prawie 69 tys. głosów a jego rywalka ponad 45 tys. głosów. Trzeba również zaznaczyć, że komitet R. Dutkiewicza miał większe poparcie niż SLD-UP, a on sam miał także zwolenników poza PO i PiS. W drugiej turze wyborów 10 listopada 2002 r. R. Dutkiewicz uzyskał znaczącą przewagę, uzyskując aż 64\% poparcia. Wybory w 2002 r. nie są łatwe do jednoznacznej oceny. Na pewno R. Dutkiewicza nie można jednoznacznie nazwać kandydatem niby-partyjnym, gdyż w wyborczych szrankach stanął jako kandydat lokalny namawiany przez polityków PiS i PO. Natomiast jego komitet wyborczy miał charakter niby-partyjny, ze względu na fakt, iż na jego listach znaleźli się politycy PO i PiS.

\footnotetext{
${ }^{28}$ FIM, Łeb w łeb. „Gazeta Wyborcza Wrocław” z dnia 23.09.2002 r.; Kto liczy na poparcie, „Gazeta Wyborcza Wrocław” z dnia 27.09.2002 r.
} 
Grażyna Szczęsna - Wybory organu wykonawczego gminy...

Pierwszą kadencję prezydent R. Dutkiewicz poświęcił na pozyskiwanie inwestorów i promocję miasta. Dzięki temu we Wrocławiu pojawili się inwestorzy: HP, LG Philips, Siemens, Toshiba, Volvo, Whirpool, Wrozamet, co spowodowało utworzenie ok. 40 tys. miejsc pracy a w konsekwencji wpłynęło na zmniejszenie bezrobocia z 14 do $9 \%{ }^{29}$. Przed wyborami w 2006 r. przede wszystkim politycy PO pokładali nadzieje, że R. Dutkiewicz będzie ubiegał się o reelekcję pod szyldem ich partii ${ }^{30}$. Natomiast on sam w dniu 24 czerwca 2006 r. oznajmił, że startuje jako niezależny kandydat, jednakże chciałby poparcia ze strony PO i PiS. Trzeba powiedzieć, że rywalizacja wyborcza w $2006 \mathrm{r}$. miała dość anemiczny przebieg. Przyczyny należy doszukiwać się w niezwykle silnej pozycji prezydenta R. Dutkiewicza na lokalnej arenie politycznej. W zasadzie zarejestrowano 12 komitetów wyborczych, ale tylko trzy, poza prezydenckim, zgłosiły swoich kandydatów. R. Dutkiewicz zdobył 84,53\% głosów pokonując kontrkandydata LPR Janusza Dobrosza ${ }^{31}$.

Można powiedzieć, że R. Dutkiewicz w 2006 r. osiągnął wielki sukces. Reelekcja z tak dużym poparciem społecznym pokazała, że dzięki widocznym efektom sprawowania władzy, jak również pomimo braku absolutnej większości w Radzie, można sprawnie zarządzać miastem. W wyniku decyzji prezydenta o zerwaniu koalicji z PO, Wrocław jak również jego władze zostały pozbawione klosza ochronnego, jaki do tej pory zapewniały władze państwowe zdominowane przez PO. Tym samym wybory samorządowe we Wrocławiu w 2010 r. zapowiadały się bardzo interesująco, jako dalszy ciąg pojedynku pomiędzy dotychczasowymi koalicjantami: obozem prezydenta R. Dutkiewicza i przede wszystkim - Platformą Obywatelską.

W 2010 r. w rywalizacji o fotel prezydenta Wrocławia uczestniczyło 9 kandydatów. Szczególną wagę do tych wyborów przywiązy-

\footnotetext{
${ }^{29}$ R. Grochal, A. Kondzińska, Dutkiewicz bezpartyjny i bezkonkurencyjny. „Gazeta Wyborcza Wrocław" z dnia 15.11.2006 r.

${ }^{30}$ AGKO, Co zrobi prezydent Dutkiewicz?, "Gazeta Wyborcza Wrocław” z dnia 21.06.2006 r.

31 Na podstawie danych PKW (www.pkw.gov.pl).
} 
wały partie polityczne - PO i PiS, wystawiając do rywalizacji posłów Sławomira Piechotę (PO) i Dawida Jackiewicza (PiS). Jednak rywalizację wyborczą wygrał zdecydowanie ponownie $\mathrm{w}$ pierwszej turze wyborów R. Dutkiewicz.

Wprawdzie poparcie dla prezydenta spadło o ok. $10 \%$ w porównaniu z poprzednią elekcją, ale i tak uzyskał imponujący wynik - 71,63\% (około 140 tys. głosów) znacząco dystansując swoich kontrkandydatów.

W listopadzie 2014 r. R. Dutkiewicz ubiegał się po raz czwarty o fotel prezydenta Wrocławia. Do walki o wrocławski ratusz stanęło 10 kandydatów. Od początku kampanii wyborczej wiadomo było, że w tych wyborach R. Dutkiewicz będzie rywalizował o urząd z Mirosławą Stachowiak-Różecką (kandydatką PiS). R. Dutkiewicz, podobnie jak P. Adamowicz w Gdańsku, o prezydenturę dwa razy walczył w drugiej turze. W 2002 r., kiedy to po raz pierwszy obejmował urząd prezydenta i w ostatnich wyborach w listopadzie $2014 \mathrm{r}$.. W pozostałych wyborach odnotowywał rekordowo wysokie poparcie: w 2006 r. 84,53\%, a w 2010 r. - 71,63\%. W pierwszej turze R. Dutkiewicz uzyskał 42,37\% głosów a jego kontrkandydatka - M. Stachowiak-Różecka uzyskała $25,80 \%{ }^{32}$. Prezydent przed wyborami związał się koalicją z PO. Partia ta poparła go w wyborach i nie wystawiła we Wrocławiu swojego kandydata. Konsekwencją porozumienia R. Dutkiewicza z PO był rozłam w jego własnym ugrupowaniu samorządowym - stowarzyszeniu Obywatelski Dolny Śląsk (ODŚ). Część samorządowców związanych dotychczas z ODŚ założyła własny komitet pod nazwą KWW „Bezpartyjni Samorządowcy”. „Rozłamowcy” podkreślali, że nie chcą być „klientami partii politycznych”. W wyborach na prezydenta stolicy Dolnego Śląska wystawili własną kandydatkę - Aldonę WiktorskąŚwięcką 33. W kampanii wyborczej pod hasłem "Łączy nas Wrocław” Dutkiewicz wymieniał priorytety programu, które chce realizować po

32 Na podstawie danych PKW (www.pkw.gov.pl).

33 http://www.tvn24.pl/rafal-dutkiewicz-o-kolejna-kadencje-musi-powalczyc-wdrugiej-turze,489030,s.html (data dostępu: 1.12.2016 r.). 
Grażyna Szczęsna - Wybory organu wykonawczego gminy...

wygranych wyborach. Do nich zaliczył m. in. powstanie nowych szkół, przedszkoli i żłobków, powstanie obwodnicy Leśnicy i alei Wielkiej Wyspy, rozbudowę systemu ścieżek rowerowych, pojawienie się pojazdów elektrycznych, zapewnienie rozwoju transportu zbiorowego i zwiększenie komfortu podróży tramwajami i autobusami poprzez wprowadzenie klimatyzacji w pojazdach. Prezydent zapewniał, że wrocławianie $\mathrm{w}$ jeszcze większym stopniu zostaną zaproszeni do decydowania o wyglądzie miejsc, w których mieszkają. Zapewniał również zwiększenie budżetu obywatelskiego. Priorytetem dla R. Dutkiewicza miało być również wspieranie gospodarki opartej na wiedzy, bo Wrocław to miasto nowych technologii, czego symbolem jest kampus EIT Plus ${ }^{34}$. Przed pierwszą turą głosowania Dutkiewicz nie był w ogóle aktywny, niemal nie prowadził kampanii. W mieście widać go było jedynie na plakatach i billboardach. Przygotował kilka konferencji, zaprezentował też znanych wrocławian zasiadających w jego komitecie honorowym, pojawiał się na konwencjach, prezentacjach kandydatów do rady miasta i sejmiku województwa. Ale odmawiał debat z rywalami. Jego sztab wyborczy wierzył w zwycięstwo i poparcie na poziomie ponad $60 \%{ }^{35}$. Gdy okazało się, że jednak będzie dogrywka, R. Dutkiewicz i jego sztab zaczęli odrabiać straty. Prezydent wyszedł z ratusza i zaczął rozmawiać z mieszkańcami, na wrocławskich przystankach indagował pasażerów i namawiał do głosowania na siebie. Zgodził się również na debatę ze swoją konkurentką, co wcześniej stanowczo odrzucał. W wywiadzie dla "Gazety Wyborczej” przyznał, że zrozumiał sygnał od wyborców i zapowiedział zmianę stylu zarządzania miastem. Obiecał też, że będzie - bardziej niż dotychczas wsłuchiwał się w opinie mieszkańców, m.in. przeznaczając jeden dzień w tygodniu na spotkania z nimi ${ }^{36}$.

34 http://www.tvn24.pl/rafal-dutkiewicz-o-kolejna-kadencje-musi-powalczyc-wdrugiej-turze,489030,s.html (data dostępu: 1.12.2016 r.).

35 M. Kozioł, Dutkiewicz schodzi do ludzi. „Gazeta Wyborcza Wrocław” z dnia 20.11.2014 r.

36 J. Harłukowicz, Dutkiewicz chyba wygrał, „Gazeta Wyborcza Wrocław” z dnia 1.12.2014 r. 
W dniu 30 listopada 2014 r. R. Dutkiewicz po raz drugi w swojej samorządowej karierze zmierzył się ze swoją kontrkandydatką do fotela szefa miasta w drugiej turze. Ostatecznie prezydent Wrocławia wygrał wybory na kolejną, czwartą kadencję wynikiem 54,72 \% głosów ${ }^{37}$. Ale odnotował najgorszy $\mathrm{w}$ historii swoich kampanii wynik wyborczy. Warto zaznaczyć, że taka tendencja miała miejsce w całym kraju, dotknęła ona większości prezydentów miast.

Dla R. Dutkiewicza były to zapewne najtrudniejsze wybory. Swój wyjątkowo słaby wynik prezydent komentował dwojako: „Rządzę Wrocławiem już 12 lat, więc naturalną rzeczą jest zatem pewne zużycie. Na pewno też nie wszystko, co robiłem, wykonywałem bezbłędnie. Na dodatek w ostatnim czasie widać wyraźny wzrost poparcia dla PiS"38. Prezydent uważa, że słabszy niż cztery i osiem lat temu wynik wyborczy to cena, jaką zapłacił za rezygnację ze swojej apartyjności (zbliżenie z Platformą Obywatelską) ${ }^{39}$.

Trzeba również powiedzieć, że wpływ na wynik wyborczy miała również słaba kampania wyborcza prezydenta. Dodatkowo przeprowadzone wybory w dwóch turach stanowią sygnał dla prezydenta, że musi zmienić styl rządzenia. Bez wątpienia czynnikiem wpływającym na przebieg i wyniki tych wyborów miało zjawisko narastającego zniecierpliwienia społeczeństwa wobec koalicji PO-PSL, krytyka tych rządów prowadzona przez PiS i wreszcie - co było skutkiem wskazanych przewartościowań w ocenach i postawach społecznych - zmiana preferencji wyborczych w wielu środowiskach.

\section{Podsumowanie}

Na podstawie analizy procesu wyłaniania organu wykonawczego w konkretnych miastach: Krakowie, Gdańsku, i Wrocławiu można

37 Na podstawie danych PKW (www.pkw.gov.pl.).

38 J. Harłukowicz, Dutkiewicz zaczyna zmiany, „Gazeta Wyborcza Wrocław” z dnia 2.12.2014 r.

39 Tamże. 
zauważyć, że większą efektywność w wyborach osiągają ci prezydenci, którzy biorą udział w wyborach w ramach komitetów lokalnych lub niby-partyjnych. Wyborcy wolą „lokalnych” prezydentów miast. Istnieją oczywiście przypadki wyjątkowe - chociażby Gdańsk, który pokazuje, że „status wiecznego prezydenta” można utrzymać w „sposób partyjny". Generalnie trzeba podkreślić, że sukces w rywalizacji wyborczej o fotel włodarza miasta może osiągnąć lokalny przywódca, opierający swą siłę na dwóch fundamentach: poparciu mieszkańców oraz zapleczu w radzie miasta.

Analiza kampanii wyborczych i wyników wyborów dowodzi również, że pierwszoplanowym warunkiem sukcesu w zabieganiu o władzę w mieście jest poparcie lokalnej społeczności. Chcąc utrzymać władzę trzeba odpowiadać na potrzeby mieszkańców w zarządzanym mieście przez akceptowaną społecznie dbałość o jego prosperity. Nie może zabraknąć trafnego odczytywania pojawiających się problemów rozwojowych miasta i oczekiwań jego mieszkańców. Właściwie można powiedzieć, że prezydenci miast to politycy na czteroletnich etatach. Reelekcję może im zagwarantować odpowiednia charyzma, osobowość, talent, pracowitość i styl przywództwa akceptowany przez społeczność lokalną ${ }^{40}$. Liczą się oczywiście osiągnięcia przypadające na okres kadencji, choć ich percepcja i ocena społeczna rządzą się swoimi, specyficznymi prawami. Wydaje się również, że kandydaci biorący udział w rywalizacji z „wiecznymi prezydentami” nie mają wystarczającej siły, by konkurować z konkretnymi faktami - rzeczywistymi dokonaniami kandydatów z poprzedniej kadencji. Według Jarosława Flisa „urzędujący prezydenci miast, decydując się na udział w wyborach, już na początku kampanii mają ok. $20 \%$ przewagi nad innymi kandydatami. Wynika to głównie z tego, że społeczeństwo dobrze ocenia władze samorządowe i udziela sporego kredytu zaufania

40 A. Lipska, Wójt, burmistrz, prezydent - lokalni liderzy polityczni czy menedżerowie?, [w:] S. Michałowski, K. Kuć-Czajkowska (red.), Przywództwo lokalne a kształtowanie demokracji partycypacyjnej, Wydawnictwo UMCS, Lublin 2008, s. 487. 
urzędującym prezydentom"41. Poza tym urzędujący prezydenci miast $\mathrm{z}$ racji pełnionej funkcji przyciągają większą uwagę mediów niż konkurenci, co na pewno zapewnia im większą rozpoznawalność i bez wątpienia ma istotny wpływ na wynik wyborów.

Wyniki moich badań pozwalają również na stwierdzenie, że proces wyłaniania prezydenta $w$ wielkim mieście, a zwłaszcza decyzje mieszkańców-wyborców spowite są pewną mgiełką tajemniczości, którą adekwatnie oddaje pojęcie imponderabiliów, kształtujących w pewnym stopniu zachowania i decyzje (wyborcze). To zaś nie poddaje się, jako „materia szczególna” metodom i narzędziom badawczych stosowanym w toku moich badań gdyż wymagałoby zastosowania instrumentarium i metodologii bardziej wyrafinowanej, właściwej dyscyplinom badającym psychologiczne aspekty społecznych zachowań, w tym zachowań wyborczych.

\section{Bibliografia:}

AGKO, Co zrobi prezydent Dutkiewicz?, „Gazeta Wyborcza Wrocław” z dnia 21.06.2006 r.

Borkowska G., Przyjaciół poznaje się w kampanii, „,Gazeta Wyborcza Trójmiasto" z dnia 12.11.2002 r.

Borkowska G., Ta wyborcza niedziela. Listy do Pawła Adamowicza, „Gazeta Wyborcza Trójmiasto" z dnia 8.11.2002 r.

FIM, Łeb $w$ łeb, „Gazeta Wyborcza Wrocław” z dnia 23.09.2002 r.; Kto liczy na poparcie, „Gazeta Wyborcza Wrocław” z dnia 27.09.2002 r.

Grochal R., Kondzińska A., Dutkiewicz bezpartyjny i bezkonkurencyjny, „Gazeta Wyborcza Wrocław" z dnia 15.11.2006 r.

Harłukowicz J., Dutkiewicz chyba wygrał, „Gazeta Wyborcza Wrocław” z dnia 1.12.2014 r.

Harłukowicz J., Dutkiewicz zaczyna zmiany, „Gazeta Wyborcza Wrocław” $\mathrm{z}$ dnia 2.12.2014 r.

Jamroż M., Narodziła się PGE Arena Gdańsk, „Gazeta Wyborcza Gdańsk” z dnia 26.05.2010 r.

41 https://www.wprost.pl/217159/Wybory-s. (data dostępu: 1.12 .2016 r.). 
Grażyna Szczęsna - Wybory organu wykonawczego gminy...

Katka K., Włodkowska K., PiS chce buszować w kolebce PO, „Gazeta Wyborcza Trójmiasto" z dnia 16.01.2006 r.

Kozioł M., Dutkiewicz schodzi do ludzi, „Gazeta Wyborcza Wrocław” z dnia 20.11.2014 r.

Kuczur T., Istota i funkcjonowanie nowoczesnego samorzqdu terytorialnego w Polsce - wprowadzenie do problematyki, [w:] R. Bruski, J. Joachimowski, T. Kuczur (red.), Współczesna administracja publiczna w Polsce, Wybrane zagadnienia prawe, polityczne i ekonomiczne, Wyd. Mado, Toruń 2010.

Lipska A., Wójt, burmistrz, prezydent - lokalni liderzy polityczni czy menedżerowie?, [w:] S. Michałowski, K. Kuć-Czajkowska (red.), Przywództwo lokalne a kształtowanie demokracji partycypacyjnej, Wydawnictwo UMCS. Lublin 2008.

Piłat B., To będzie kadencja administrowania, „Gazeta Wyborcza Kraków” $\mathrm{z}$ dnia 01.12.2014 r.

Piotrkowski P., Katka K., Oceniamy bezpieczeństwo, „Gazeta Wyborcza Trójmiasto" z dnia 30.11.2004 r.

Żurek R., Recepta na „długowiecznośc” wójta. Analiza czynników prowadzqcych do reelekcji w wyborach 2010 r. na wybranych przykładach, „Prace Naukowe Akademii im. Jana Długosza w Częstochowie. Res Politicae" 2012, „Wydanie specjalne: Samorząd miejski i jego elity”. 